\title{
Macunaíma, um malandro alegórico
}

\author{
Macunaíma, an allegorical rogue
}

\author{
Renato Amado* \\ renato_barreto@brown.edu \\ Brown University
}

\begin{abstract}
RESUMO: Pretende-se demonstrar, neste artigo, que Macunaíma é um malandro. Para isso, é feita uma apresentação de tal conceito, de acordo com a obra de Roberto DaMatta, Carnavais, malandros e heróis, cotejando-o com as definições de renunciador e de caxias, igualmente apresentadas pelo antropólogo. São extraídas as características essenciais do malandro e é verificado se Macunaíma as possui. Chega-se a uma resposta afirmativa, o que leva à conclusão de que o personagem marioandradiano é um malandro. Passa-se a um breve estudo da alegoria e a uma análise do caráter alegórico de Macunaíma, buscando-se compreender o que pretendeu o autor do clássico modernista ao criar um protagonista que é uma alegoria de um trickster mitológico, qual seja, Makunaima. Ao final do artigo, esperase que reste demonstrado que Macunaíma não é o ansiado herói nacional, pois tal função redentora caberá a um renunciador, não a um malandro, pelas razões que foram apresentadas.
\end{abstract}

PALAVRAS-CHAVE: Macunaíma. Malandro. Trickster. Makunaima. Alegoria.

ABSTRACT: This article seeks to demonstrate that Macunaíma is a malandro (rogue). To accomplish this, a presentation of such a concept is made, comparing it with the definitions of renunciator and caxias (squared), all of which are in accordance with the work of Roberto DaMatta. The essential characteristics of the malandro are identified, and it is verified if Macunaíma possesses them. We come to an affirmative answer, which leads us to the conclusion that the Andrade's character is a malandro. A brief study of allegory and an analysis of the allegorical character of Macunaíma is done, seeking to understand what Andrade intended in creating a protagonist who is an allegory of a mythological trickster, Makunaima. At the end of the article, we intend to have demonstrated that Macunaíma is not the longed-for national hero, because this redemptive function is for a renunciator, not a malandro.

KEYWORDS: Macunaíma. Malandro. Trickster. Makunaima. Allegory.

\footnotetext{
* Mestre em Literatura Brasileira pela UERJ e doutorando em Portuguese and Brazilian Studies pela Brown University.
} 


\title{
Introdução
}

Pretendemos demonstrar, no decorrer deste estudo, que Macunaíma, o protagonista do principal romance marioandrariano, é um típico malandro. Para isso, vamos identificar quais são as principais características deste tipo e, então, verificar, uma a uma, se Macunaíma as possui. Ao final, verificaremos algumas consequências dessa conclusão.

Traçaremos o conceito de malandro sobretudo a partir do capítulo "Pedro Malasartes e os Paradoxos da Malandragem", da obra seminal de Roberto DaMatta, Carnavais, malandros e heróis. DaMatta (19883) identifica três tipos de personagens nacionais: o caxias, o renunciador e o malandro.

O renunciador é aquele que pratica a renúncia em busca de uma ascensão. Nas palavras do estudioso:

\begin{abstract}
Realmente, sempre começamos com alguém muito pobre e desgraçado, alguém que está lá embaixo, nos porões do mundo social. E obviamente terminamos com sua ascensão social fulminante, quando geralmente se casa com a filha do Rei ou, modernamente e na televisão, com a filha do magnata. Mas, e este ponto precisa ser bem acentuado, naquela personagem havia pobreza e desgraça, mas nunca mediocridade ou falta de nobreza. De fato, o sujeito estava muito bem marcado desde o início da estória por algum sinal particular, traço ineludível do seu caráter especial, sempre revelado para nós de modo substantivo, quer dizer, por meio de algum sinal intrínseco, interno à personalidade do herói (DAMATTA, 1983, p. 199-200).
\end{abstract}

O herói renunciador nacional, segundo o autor, deseja estabelecer uma nova realidade (1983, p. 205), "promete um mundo novo, um universo social alternativo" (DAMATTA, 1983, p. 206). O renunciador é "o verdadeiro revolucionário num universo social hierarquizante" (DAMATTA, 1983, p. 206).

O caxias, cujo nome é derivado - segundo o mesmo DaMatta - do patrono de Exército, Duque de Caxias, representa o domínio da lei, das vertentes formais e controladas. O caxias tem uma leitura do mundo baseada em "regras, leis, decretos, regulamentos, portarias e regimentos" (DAMATTA, 1983, p. 205). Ao caxias, importa a harmonia do conjunto, garantida pela hierarquização, pela lei e pela ordem. Ele é, portanto, um conservador, guiado por algo externo ao sujeito, por uma ordem uniformizadora, que mantém a coesão social tal como está. $O$ caxias pode ser tanto aquele que, no topo da pirâmide social, mantém a ordem, seja em funções de 
controle ou legislativas, como o que segue a ordem imposta por terceiros. Nesta hipótese, caso tenha uma crença cega no sistema, desviará para a subcategoria otário (DAMATTA, 1983, p. 208), sendo apenas um "cego e fiel servidor, isto é, o cidadão que acaba por tornar-se ingênuo e quadrado. Daí a transformar-se num otário completo, isto é, o homem comum e crédulo, sempre pronto a obedecer e nunca a comandar, e por isso mesmo se constituindo na eterna e predileta vítima dos malandros, é um passo" (DAMATTA, 1983, p. 208, grifos do autor). O caxias é, em suma, o seguidor de leis, o absolutamente leal, o patriota honesto e crédulo, dentre outros (exemplos de DaMatta, 1983, p. 208).

\section{Do Malandro}

Debrucemo-nos, agora, sobre o malandro, que é o que mais interessa ao escopo deste estudo.

O mundo da malandragem é o oposto do universo do caxias. Enquanto este é determinado pelo exterior, importando "a totalidade e a hierarquização" (DAMATTA, 1983, p. 205), ao malandro importam os impulsos criativos e a liberdade. O universo do malandro é individualizado (1983, p. 204) e de certo modo indiferente ao resultado que deriva do conjunto de indivíduos. Enquanto a parada militar é a manifestação, por excelência, do caxias, o carnaval é o momento do malandro: indivíduos exercendo sua liberdade criativa de forma relativamente independente uns dos outros, sem qualquer organização, em um cenário caótico e fragmentário.

No mundo (...) da malandragem, o que conta é a voz, o sentimento e a improvisação: aquilo que, em nossa sociedade, é definido como pertencendo ao "coração" e ao "sentimento". Vale, assim, o que está lá dentro, dentro das emoções e do coração. No universo da malandragem, é o coração que inventa as regras. No mundo das paradas, porém, o importante é o exterior: medalhas, uniformes, armas, formas fixas de conduta, continências e reverências (DAMATTA, 1983, p. 205).

Roberto da Matta (1983) identifica Pedro Malasartes como o paradigma do malandro. Trata-se de personagem tradicional das culturas brasileira e portuguesa, já recontado em diversas histórias. Faremos uma breve digressão sobre Malasartes, pois, sendo ele - para DaMatta - uma espécie de malandro arquetípico, as características que lhe são apontadas aplicar-se-ão ao malandro em geral, servindo, portanto, para iluminar nossa análise acerca de Macunaíma como malandro. 
Pedro Malasartes é um bufão astucioso e vadio, que vive em uma família composta por seus pais, ambos idosos, e seu irmão mais velho, João. João consegue emprego em uma fazenda cujo proprietário é rico e velhaco. $\mathrm{O}$ fazendeiro tem um contrato impessoal que rege sua relação com todos os seus trabalhadores, que dispõe o seguinte: a) o funcionário não pode rejeitar serviço; b) nem o funcionário nem o patrão podem ficar zangados; c) quem descumprir quaisquer destas condições terá uma tira de couro arrancada desde o pescoço até o fim das costas (DAMATTA, 1983, p. 215). Efetivamente, João acaba por perder uma tira de couro. Malasartes vai, então, vingar seu irmão, o que é feito por meio de planos astuciosos. São seis os casos trazidos à baila por DaMatta. Vejamos alguns deles:

1. O patrão manda que Pedro vá trabalhar numa plantação de milho e envia uma cachorrinha para acompanhá-lo. O trato é que Pedro só pode voltar para casa quando a cachorra assim o fizer. Depois de meio dia de trabalho, e como o animal nem se mexe, Malasartes logo vê que é um golpe, e dá uma paulada na cachorrinha, a qual corre para casa. Pedro pode então voltar. À tarde, só faz o gesto e o animal volta. Pedro assim derrota o fazendeiro, pois este fica zangado, mas - pelo mesmo contrato - não o pode demonstrar.

2. No dia seguinte, o patrão manda Pedro limpar a roça de mandioca. Pedro arranca toda a plantação, deixando tudo realmente limpo. Diante do patrão zangado, Pedro perguntou se ele está satisfeito. Para não perder, o patrão afirma que sim, e perde novamente.

3. No outro dia, a tarefa era que Pedro trouxesse um carro de bois cheio de "pau sem nós". Malasartes cortou todo o bananal, epxlicando que bananeira é pau sem nó. $O$ fazendeiro perde novamente, pois fica zangado, mas não pode demonstrar.

4. No dia seguinte, Pedro devia colocar um carro de bois, com bois e tudo, dentro de uma casinha, sem passar pela porta. O Pedro cortou os bois e o carro e jogou tudo pela janela adentro. $O$ patrão novamente esconde a zanga e perde.

(...)

6. Vendo que com aquele empregado perdia tudo, o fazendeiro resolveu matá-lo. Disse que um ladrão rondava o curral e que ambos, armados, deviam vigiar para prendê-lo. A ideia era atirar em Pedro e dizer que havia pensado que ele era o ladrão. De noite, o fazendeiro foi para o curral e Pedro deveria substitúi-lo ao primeiro cantar do galo. Quando o galo cantou, Malasartes acordou a mulher do patrão e disse-lhe que seu marido queria vê-la no curral. A velha apareceu e foi morta por seu marido. Pedro apareceu e acusou o patrão de assassinato. Este, assombrado, pagou muito dinheiro para não haver conhecimento da justiça e ofereceu mais dinheiro ainda para Malasartes desaparecer de sua fazenda. O rapaz aceitou e voltou rico para a casa dos pais (DAMATTA, 1983, p. 228).

que Malasartes faz é seguir o contrato ao pé da letra e, por esse meio, consegue derrotar o fazendeiro, obtendo a vingança e enriquecendo. 
O poderio do fazendeiro advém das suas riquezas, ou seja, de algo externo a ele. Uma vez perdidos os bens, perdido o poder. O poder de Malasartes, por seu turno, advém de qualidades intrínsecas, portanto irremovíveis. Como dito anteriormente, é o universo interior, a criatividade individual, que importa para o malandro.

Nota-se uma função mediadora na ação do herói, entre riqueza e pobreza pois pela narrativa conclui-se que não é possível ascensão pelos modos tradicionais; há uma relação inalterável entre explorador e explorado, pelos termos do contrato impessoal do fazendeiro. Malasartes, ao vingar o irmão, age como um elemento de equilíbrio social, atuando nas brechas, no espaço vazio deixado pelo contrato impessoal, por meio da sua pessoalização, ou seja, aplica o contrato impessoal, de forma pessoal, reescrevendo a relação de trabalho. Isso leva Roberto DaMatta a afirmar que Malasartes faz uma mediação pela vingança (1983, p. 226).

Outra característica típica do malandro, que se manifesta de forma flagrante em Malasartes, é a "recusa em transacionar comercialmente com a própria força de trabalho" (DAMATTA, 1983, p. 226), pois o malandro prefere "reter para si sua força de trabalho e suas qualificações" (DAMATTA, 1983, p. 226). Em outras palavras, trata-se do vadio, que:

não entra no sistema com sua força de trabalho, e fica flutuando na estrutura social, podendo nela entrar ou sair ou, ainda, a ela transcender. A astúcia, por seu turno, pode ser vista como um equivalente do jeito (ou do jeitinho), como um modo estruturalmente definido de utilizar as regras vigentes na ordem em proveito próprio (DAMATTA, 1983, p. 226, grifos do autor).

Ele é, portanto, um ser marginal, que tangencia o universo das relações sociais de trabalho, "articulando signos de dois mundos e não pertencendo inteiramente a nenhum" (MATOS, 1982, p. 59), o que faz dele um ser ambíguo e liminar.

Considerando-se que 0 autor toma Pedro Malasartes por malandro paradigma, a partir da sua narrativa é possível extrair algumas características dos malandros, as quais listamos, acrescentando, ainda, outras citadas por Roberto da Matta: astúcia; ausência de um caráter definido, o que the confere maleabilidade; função mediadora; vadiagem; homem de interstícios (1983, p. 213), ambíguo e liminar; relativizador da ordem e moral vigentes (1983, p. 214).

Verifiquemos se Macunaíma possui as características acima citadas. 


\section{Macunaíma, um Malandro}

\subsection{Astúcia}

A astúcia é uma das aptidões mais patentes de Macunaíma. Em se tratando de um ser com certo caráter místico, ele muitas vezes se transforma em animais para enganar pessoas. Vejamos os seguintes exemplos:

- Transforma-se em formiga e então em pé de urucum, para conquistar Iriqui, a companheira de seu irmão Jiguê. Cito o trecho:

No outro dia os manos foram pescar e caçar, a velha foi no roçado e Macunaíma ficou só com a companheira de Jiguê. .Então ele virou na formiga quenquém e mordeu Iriqui para fazer festa nela. Mas a moça atirou a quenquém longe. Então Macunaíma virou num pé de urucum. A linda Iriqui riu, colheu as sementes se faceirou toda pintando a cara e os distintivos. Ficou lindíssima. Então Macunaíma, de gostoso, virou gente outra feita e morou com a companheira de Jiguê (ANDRADE, 2007, p. 26).

Três vezes transforma-se no peixe aimará para roubar o anzol de um pescador. Mas, como tal animal não tem dentição para tal, vira, então, numa piranha, e consegue subtrair o anzol (ANDRADE, 2007, p. 132).

Em outro episódio, sem necessitar passar por uma transformação metafísica, traveste-se de francesa para enganar o gigante Piaimã e tentar recuperar a muiraquitã, seu amuleto que estava em poder do gigante (ANDRADE, 2007, p. 64).

É também a astúcia que lhe permite matar o seu inimigo. Ele consegue convencer o gigante a ir num balanço com espinhos. Ele dá um tranco que faz Piaimã sangrar. Embaixo, a esposa do seu adversário recolhia o sangue que caía, como era costume, para usar de molho em uma macarronada, sem saber que, dessa vez, se tratava do sangue do próprio marido. Após mais um arranco no balanço, o gigante cai pelo buraco que tinha embaixo, dentro da panela com macarronada fervente, assim morrendo (ANDRADE, 2007, p. 170).

Não resta dúvida, portanto, que Macunaíma é um personagem astuto, valendo-se, muitas vezes, do seu poder de mimetizar ou transformar-se em algo distinto, para conseguir seus objetivos.

\subsection{Ausência de um caráter definido}


Macunaíma é um ser que vive, essencialmente, no princípio do prazer. Tal princípio, estabelecido por Freud, "se refere ao propósito dominante da atividade psíquica, sobretudo em seu nascedouro: evitar o desprazer e buscar o prazer" (BARRETO, 2016, p. 213), a qualquer custo, sem considerações de ordem prática. Por exemplo, alguém tomado pelo princípio do prazer não suspenderá sua alimentação para evitar a sensação de excessiva satisfação que virá em seguida ou, muito menos, para que tenha reserva de suprimentos nos dias vindouros. Posteriormente, contudo, o ser humano percebe que às vezes é vantajoso limitar o prazer no momento para garantir um nível relativamente estável de prazer no futuro. Ou, em outras palavras, como dissemos em outra oportunidade:

Com o princípio da realidade, o ser humano torna-se mais pragmático e realista. Ciente da inviabilidade de obter prazer ou evitar o desprazer a todo instante, uma vez que o mundo oferece recursos limitados para desejos ilimitados, a pessoa passa a negociar com o meio, a calcular a melhor ação para que tenha sempre a menor tensão possível em seu aparelho psíquico, mesmo que isso signifique não realizar uma descarga completa de tensões em algumas hipóteses em que isso parece viável. Trazendo para termos práticos da vida cotidiana, podemos, dentre incontáveis hipóteses, pensar no exemplo do concursando, que adia diversos prazeres para estudar, em prol da obtenção futura de um salário que Ihe permitirá um acesso constante a objetos que Ihe trarão prazer. É importante notar, portanto, que o princípio da realidade joga favoravelmente ao prazer, buscando mantê-lo o mais constante possível, mesmo que isso imponha algumas limitações na sua intensidade (BARRETO, 2016, p. 216).

Trata-se, portanto, de um aprendizado, visando a uma solução pragmática diante da limitação de recursos disponíveis para desejos ilimitados.

Macunaíma, no entanto, poucas vezes é capaz de alguma atitude de contenção. Apenas quando traça planos para recuperar a sua muiraquitã, em poder do Gigante Piaimã, consegue fazer planos, conter-se, deixar o princípio da realidade manifestar-se. Em geral, é um escravo das pulsões, buscando o prazer e evitando o desprazer, sem considerações de outras ordens, inclusive éticas. Por isso, faz coisas como comer toda a comida da família, sem deixar nada para os irmãos. Vale igualmente lembrar que sua primeira relação carnal com a amada Ci se dá mediante estupro (ANDRADE, 2017, p. 31-32). Ao ver alguém que the desperte desejo, aquele dominado exclusivamente pelo princípio do prazer, fará o que estiver ao seu alcance para realizá-lo, ignorando a vontade (ou falta dela) da outra parte ou questões morais. 
Pode-se dizer, portanto, que o sujeito tomado pelo princípio do prazer não tem um caráter definido, é apenas guiado pelos estímulos recebidos pelos sentidos. Buscará atender a esses estímulos da forma que for possível: essa é sua meta. Em busca de realizá-la, não se fará coerente com um sistema de valores $A$ ou $B$, o que indica a ausência de um caráter que o defina.

Mas não é só por isso que Macunaíma é um herói sem nenhum caráter. Quando está em busca da muiraquitã, ele demonstra um grau um pouco maior de maturidade, valendo-se do princípio da realidade ${ }^{1}$. Nesse momento, ainda assim, ele continua sendo sem caráter e fica mais flexível e astuto, pois não é escravo das pulsões, podendo elaborar planos mais sofisticados. É que a falta de caráter deriva (ou determina) também - e sobretudo neste momento - da sua liminaridade, como veremos abaixo.

\subsection{Um ser liminar}

Aquele que não tem caráter, não está comprometido com nenhuma lógica, sistema de valores, universo ou lado. Por isso o malandro está num entre-lugar, ou seja, em um espaço entre diferentes códigos. O malandro transita por vários lugares, mas sem estar vinculado a nenhum deles. Assim é Macunaíma, um índio que nasce preto retinto e fica branco. Um autóctone que tem um embate com o capitalista Venceslau Pietro Pietra, mas que, quando é resgatado de uma ilha pelas filhas de Véi, a sol, troca as moças por uma portuguesa. Gilda de Mello e Souza trata, em trecho que vale a pena citar, dessa contradição:

As filhas de Vei - "filhas da luz", "filhas do calor"- representam as grandes civilizações tropicais como a Índia, o Peru, o México, o Egito, civilizações que se realizaram em torno de valores culturais muito diversos do Ocidente e que teriam se harmonizado melhor com as nossas condições geográficas e climáticas. Por conseguinte, posto na situação de escolher entre as filhas de Vei e a portuguesa (o Ocidente), Macunaíma devia ter optado pela primeira; esta seria a decisão acertada, coerente com a ação central do livro, a busca do amuleto. Agindo assim, o herói estaria inscrevendo o seu destino no âmbito do Uraricoera, dando coerência à luta com o gigante e fazendo jus à recuperação da muiraquitã. Enfim, estaria se esforçando por "se organizar numa vida legítima e funcional", que

\footnotetext{
${ }^{1}$ A demonstração de que Macunaíma age guiado pelo princípio da realidade quando está em busca da muiraquitã foge ao escopo deste estudo e nos levaria a um grande desvio. Desse modo, para verificar os argumentos que usamos para sustentar esta posição, remetemos a texto publicado pelo autor deste artigo (2016).
} 
transformasse "o caos interior de suas disposições naturais num cosmo organizado em torno de um centro de gravidade". Ao contrário, a escolha que efetua - inicialmente da portuguesa e, no final da narrativa, de Dona Sancha (pois ludibriado por Vei toma a uiara ameríndia por uma das filhas de mani) - estava em desacordo com a aventura em que se lançara: representava uma acomodação aos princípios cristãos europeus e estabelecia, portanto, uma relação desarmoniosa entre o núcleo de sua personalidade e uma civilização que correspondia a "outras necessidades sociais e outros climas" (SOUZA, 2003, p. 56-57).

Índio, negro e branco e ao mesmo tempo nenhuma dessas raças. Assim é Macunaíma, sem caráter e um homem dos interstícios, pois ao ser de todos os lugares, não é de nenhum, é um habitante do entre-lugar que navega habilmente entre diferentes mundos, de acordo com as conveniências. Em resumo, Macunaíma é um ser liminar por não ter caráter e não tem caráter por ser um ser liminar.

\subsection{Função mediadora}

Macunaíma é um mediador entre o humano e a natureza. Como já nos manifestamos em estudo anterior:

O protagonista andradiano é um índio, portanto vive em espécie de simbiose com a natureza. O silvícola vê a natureza como fonte de subsistência e simultaneamente como ameaça. Para estabelecer-se como sedentário, precisa realizar uma punção controlada dos subsídios dados por ela. Mas Macunaíma se transforma em formiga quenquém; em caxipara, que é macho da formiga saúva; em aimará (espécie de peixe); em piranha feroz. Nota-se que, em geral, o herói se metamorfoseia em algum ser da natureza para fazer oposição ao humano e, muitas vezes, vira animais nocivos. Transforma-se em formiga quenquém para morder Iriqui; em caxipara para espiar se o gigante Piaimã terá medo de Chuvisco. Ele também vira aimará, uma espécie de peixe, para enganar um pescador e roubar seu anzol. Sua estratégia não funciona, então transforma-se em piranha para fazê-lo, engolindo e subtraindo o anzol do pescador (BARRETO e OLIVEIRA, 2016, p. 283).

Neste último episódio, notamos que o herói se transforma num animal para subtrair o bem de um ser humano, mas trata-se de um aparato que tem justamente a função de aprimorar a punção da natureza. Esta passagem deixa clara sua função mediadora e sua falta de alinhamento com qualquer dos lados.

Ele é, também, um mediador entre culturas. Como já dito, trata-se de um índio que nasce negro e depois fica branco. Ele, em alguns momentos, é um 
legítimo representante dos valores autóctones, em outros parece se interessar mais pelos valores europeus. O fato é que, ao final de sua saga, Macunaíma retorna para a beira do rio Uraricoera trazendo bens da metrópole. Na cidade, explica, de forma mitológica, a existência do cruzeiro do sul. Por fim, numa clara atitude antropofágica/mediadora, usa bens da metrópole ao seu bel prazer, por exemplo, transformando relógio e revólver em brincos.

\subsection{Vadiagem}

Voltamos a citar a afirmação de Roberto DaMatta, segundo a qual vadio "é aquele que não entra no sistema com sua força de trabalho, e fica flutuando na estrutura social, podendo nela entrar ou sair ou, ainda, a ela transcender" (DAMATTA, 1983, p. 226). Parece que restam poucas dúvidas de que Macunaíma se enquadra nesta categoria. Se não, vejamos.

A primeira e principal estrutura social em que Macunaíma se insere é sua família. Mas mesmo nela flutua, marginalizando-se ou aprofundando sua relação. Filho caçula que "ficava no canto da maloca, trepado no jirau de paxiúba, espiando o trabalho dos outros" (ANDRADE, 2007, p. 13). Além disso, recusa-se a falar por anos. Por esses meios, desde logo Macunaíma afirma sua posição nãocomprometida e independente em relação àquele microcosmo social. Esse desalinhamento é expresso inúmeras vezes, por diversas ações. Logo na primeira página do romance é explicitado seu hábito de pôr as mãos nas graças das cunhatãs que dele se aproximavam para fazer festinha, ou de cuspir na cara dos homens.

Seu desalinhamento em relação à família (a estrutura social em que está inserido) é tal que acaba por ser expulso pela mãe, após sonegar comida para os irmãos, em um momento em que a família passava fome por conta de uma enchente.

Sua recusa a entrar nesse sistema social com a força de trabalho é igualmente latente. Não vai caçar com os irmãos e fica na maloca com a companheira de um deles (ANDRADE, 2007, p. 26); quando voltam para a beira do Uraricoera, depois da aventura paulistana, encontram terra arrasada e há grande dificuldade em conseguir comida. Os irmãos vão à caça, enquanto Macunaíma descansa e dorme (ANDRADE, 2007, p. 188). Enfim, o herói sem caráter é um vadio cujo lema pode ser resumido pela sua libertadora frase: "Ai! que preguiça...". 
A cidade grande é válida para Macunaíma enquanto pode usá-la hedonisticamente e para procurar a muiraquitã. Entrar em seu sistema está fora de questão, não à toa o herói escreve uma carta às icamiabas pedindo dinheiro, já que não trabalhava. Confirmando sua negação ao sistema, constitui um universo social composto sobretudo de figuras marginais, como mulheres de programa - pessoas que se encaixam de forma transversal na estrutura social.

\subsection{Relativizador da ordem e moral vigentes}

Afirma, Roberto DaMatta, acerca de Pedro Malasartes:

(...) nosso personagem pode ser tomado como modelo prototípico do malandro e do herói das zonas ambíguas da ordem social, quando é difícil dizer onde está o certo e o errado, o justo e o injusto. É, como Macunaíma, um relativizador das leis, regulamentos, códigos e moralidades que sufocam o indivíduo sem berço no jugo do trabalho e servem para perpetuar as injustiças sociais (DAMATTA, 1983, p. 214).

Ao agir de forma independente dos regramentos sociais, o malandro acaba, por tabela, os relativizando.

De fato, DaMatta acerta ao afirmar que Macunaíma é um relativizador da ordem, o que é uma consequência de seu não-alinhamento. Lembremos que Macunaíma, um índio do interior de Roraima, enfrenta o industrial Venceslau Pietro Pietra e o derrota; por outro lado, cai de amores pelos valores ocidentais, preferindo uma portuguesa às filhas de Véi, a sol. Como disse Gilda de Melo e Souza, ao fazer essa escolha, o herói abre mão de "se organizar numa vida legítima e funcional" (SOUZA, 2003, p. 56), que transformasse "o caos interior de suas disposições naturais num cosmo organizado em torno de um centro de gravidade" (SOUZA, 2003, p. 57). Macunaíma surpreende; quando dele se espera uma determinada atitude, por parecer a mais lógica para o personagem, ele adota outra, o que reafirma sua ausência de caráter e acaba por relativizar nossas expectativas e valores, em função do impacto causado no leitor por essas ações independentes e arbitrárias. O malandro acaba por apontar novos caminhos.

Por todo o demonstrado acima, nos parece que não há dúvida de que Macunaíma é um malandro. 


\section{Um Malandro Alegórico}

Catarina Pereira e Mariana Sebastiana Guedes destacam o caráter alegórico da obra de Mário de Andrade. Veem, com acuidade, uma referência à alegoria das três raças na cena em que Macunaíma e seus irmãos se deparam com a fonte mágica, que deixa Macunaíma branco, Maanape com uma cor intermediária (índio) e Jiguê permanece negro, pois a água já havia se "sujado" com a cor que saíra da pele dos outros dois irmãos. Afirmam:

Mário de Andrade ao colocar as figuras dos três irmãos na narrativa, configurou a alegoria das três raças tristes, que formaram inicialmente o cerne que deu vida a toda população que viria, depois de um processo longo a ser chamada de brasileira (PEREIRA e GUEDES, 2016, p. 9).

Contudo, podemos ver no próprio Macunaíma, isoladamente, a alegoria das três raças;, afinal, como já dissemos, trata-se de um índio negro, que fica branco. Essa leitura alegórica do personagem em relação ao nacional nos leva a uma questão relevante quando constatamos que Macunaíma é um malandro.

A alegoria, nas palavras de Sérgio Paulo Rouanet, comentando texto de Walter Benjamin acerca do tema, é "figura pela qual, falando de uma coisa, queremos significar outra" (ROUANET, 1984, p. 37). O que ocorre, na alegoria, é que um elemento é retirado de seu contexto original e posto em outro contexto, significando algo diverso. É um processo que ocorre em duas etapas. Segundo Lauro Junkes:

Verifica-se primeiramente um processo de desconstrução, como descontextualização e dessemantização. O alegorista secciona um elemento de seu contexto específico e, livrando-o da sua dimensão sintática, o descontextualiza. Na sua posição e função específica no contexto anterior, o elemento servia de signo, mas a sua descontextualização provoca sua dessemantizaçao, tornando-o mero objeto sem sentido em si, fragmento que, fora do contexto, não mais conserva o sentido que aquele Ihe atribuía. A perda da dimensão sintática é acompanhada da perda da sua dimensão semântica, processando-se uma desconstrução do elemento como signo - não tem ele mais função de signo num contexto, restando apenas um elemento sem contexto e sem sentido.

Numa segunda fase, ocorre um processo de reconstrução, por nova contextualização e semantização, comportando intertextualidade. Pode o alegorista atribuir novo sentido ao fragmento, situando-o em outro contexto. (...) A escolha do novo contexto depende apenas de condições subjetivas do alegorista, não seguindo necessidades objetivas (JUNKES, 1984, p. 132). 
Por consequência, a alegoria tem um caráter fragmentário, pois arrancam-se fragmentos de certos contextos, reunindo-os com ressignificação semântica em um novo contexto. Exatamente como ocorre em Macunaíma: o herói sem nenhum caráter. Macunaíma é uma colcha de retalhos de diversos mitos e lendas nacionais, como bem demonstrou Cavalcante Proença (1978). Mas, particularmente, o que pretendia Mário de Andrade, ao recortar da mitologia o herói transnacional Makunaima $^{2}$, e ressignificá-lo como Macunaíma?

A primeira coisa que devemos pontuar é que ao escolher um determinado elemento de certo contexto para ressignificá-lo, o alegorista implica algo. Como diz Junke: "como o fragmento $X$ transposto traz consigo traços do contexto anterior, ele não só é influenciado ou determinando pelo sentido do novo contexto, mas ao mesmo tempo altera esse contexto, estabelecendo uma relação entre o segundo e o primeiro contexto" (JUNKES, 1984, p. 133).

Para decifrar a alegoria marioandradiana, precisamos, portanto, primeiro entender quem é Makunaima. Makunaima é grande herói mitológico dos povos Pemon, que vivem na região do Circun-Roraima. Essa região abarca partes do território do Brasil, Guiana e Venezuela. Trata-se, portanto, de um herói transnacional.

Ele detém características de um trickster, ou seja, um herói bufão, que transita entre diferentes mundos, fazendo a mediação entre eles, ao mesmo tempo em que desrespeita suas regras e convenções. Os tricksters costumam seguir um ciclo. A princípio são seres ingênuos e praticamente inconscientes, tomados pelo princípio do prazer. É comum, em seus ciclos, haver alguma fonte inesgotável de alimentos, até que, por conta de uma falta de contenção do trickster, essa fonte se esgota.

Essa era o caso de Makunaima, que tinha a árvore Wakazá, que fornecia todos os frutos. Mas Makunaima a derrubou, provocando uma enchente universal (KOCK-GRÜNBERG, 2002, p. 59-64).

\footnotetext{
${ }^{2}$ Kock-Grümberg, o antropólogo alemão que transcreveu as lendas dos índios Pemon, usa a grafia "Makunaíma". Contudo, em visita ao Monte Roraima, tivemos a oportunidade de conversar com índios de Parateipuy - comunidade arekuna, povo que está entre os Pemon, localizada próxima à base do Monte - e com guias que foram enfáticos em afirmar que a letra tônica da palavra é o segundo "a". Como afirmam Fábio Almeida de Carvalho e José Luis Jobim, "Makunaima" é a designação corrente entre os índios Pemon e os regionais de Roraima" (CARVALHO e ALVIM, 2009, p. 13). Deste modo optamos, neste estudo, pela grafia sem o acento agudo.
} 
Após destruir a fonte inesgotável de alimento, o trickster vê-se obrigado a desenvolver alguma astúcia para obter comida. Ele então observa os animais e passa a mimetizá-los. Em outras palavras, vai aprendendo técnicas. No ciclo de vários tricksters, há um momento em que ele renuncia prazeres imediatos para obter (ou aprender) algo que o colocará em um novo patamar no cosmo em que se insere. Vejamos, a título de exemplo, o que faz Exu, trickster do povo ioruba, introduzido na América pelos escravos africanos:

Exu não tinha riqueza, não tinha fazenda, não tinha rio, não tinha profissão, nem artes, nem missão.

Exu vagabundeava pelo mundo sem paradeiro.

Então um dia, Exu passou a ir à casa de Oxalá. la à casa de Oxalá todos os dias.

Na casa de Oxalá, Exu se distraía, vendo o velho fabricando os seres humanos.

Muitos e muitos também vinham visitar Oxalá, mas ali ficavam pouco.

Quatro dias, oito dias, e nada aprendiam.

Traziam oferendas, viam o velho orixá, apreciavam sua obra e partiam.

Exu ficou na casa de Oxalá dezesseis anos.

Exu prestava muita atenção na modelagem

e aprendeu como Oxalá fabricava

as mãos, os pés, a boca, os olhos, o pênis dos homens,

as mãos, os pés, a boca, os olhos, a vagina das mulheres.

Durante dezesseis anos ali ficou ajudando o velho orixá.

Exu não perguntava.

Exu observava.

Exu prestava atenção.

Exu aprendeu tudo.

Um dia Oxalá disse a Exu para ir postar-se na encruzilhada por onde passavam os que vinham à sua casa.

Para ficar ali e não deixar passar quem não trouxesse

uma oferenda a Oxalá.

Cada vez mais havia mais humanos para Oxalá fazer.

Oxalá não queria perder tempo

recolhendo os presentes que todos lhe ofereciam.

Oxalá nem tinha tempo para as visitas.

Exu tinha aprendido tudo e agora podia ajudar Oxalá.

Exu coletava os ebós para Oxalá.

Exu recebia as oferendas e as entregava a Oxalá.

Exu fazia bem o seu trabalho

e Oxalá decidiu recompensá-lo.

Assim, quem viesse à casa de Oxalá

teria que pagar também alguma coisa a Exu.

Quem estivesse voltando da casa de Oxalá

também pagaria alguma coisa a Exu.

Exu mantinha-se sempre a postos

guardando a casa de Oxalá.

Armado de um ogó, poderoso porrete,

afastava os indesejáveis 
e punia quem tentasse burlar sua vigilância.

Exu trabalhava demais e fez ali sua casa,

ali na encruzilhada.

Ganhou uma rendosa profissão, ganhou seu lugar, sua casa.

Exu ficou rico e poderoso.

Ninguém pode mais passar pela encruzilhada

sem pagar alguma coisa a Exu (PRANDI, 2001, p. 40-41).

Makunaima também passa a dominar técnicas. Por exemplo, conforme nos ensina Koch-Grünberg, aprende a rastrear e a cercar peixes, facilitando a pescaria (2002, p. 65). O trickster, portanto, passa por um processo de aprendizado, tornando-se um artífice que o faz ascender no cosmo em que se insere. Todo aprendizado necessita renúncia, contenção (afastamento do princípio do prazer, em prol do princípio da realidade). O trickster, neste ponto, aproxima-se do renunciador a que se refere Roberto DaMatta (1983).

Macunaíma não aprende novas técnicas, não se contém, não renuncia. Por isso, em outras oportunidades (BARRETO, 2016, p. 211; BARRETO; OLIVEIRA, 2016, p. 298) dissemos que ele é um trickster de ciclo incompleto. Mas bem poderíamos tê-lo definido, como aqui o fazemos, como malandro, pois a diferença essencial entre o trickster e o malandro é que aquele ascende no cosmo social, por meio da renúncia, ao passo que este não pratica a renúncia e mantém-se sempre marginal, como ocorre com Macunaíma.

O que faz, então, Mário de Andrade, ao ressignificar um trickster como malandro? Em se tratando de tipos com diversas semelhanças, ficam ressaltadas as diferenças. Uma delas é a ausência de renúncia no malandro. Essa diferença latente é reforçada pelo final da saga, em que Macunaíma desiste do mundo, retirando-se para o cosmo, numa morte simbólica, porque não consegue ter o mínimo de organização para se adaptar ao mundo, reconhecendo-se como demasiado caótico:

Um momento pensou mesmo em morar na cidade da Pedra com o enérgico Delmiro Gouveia, porém Ihe faltou ânimo. Pra viver lá, assim como tinha vivido era impossível. Até era por causa disso mesmo que não achava mais graça na Terra... Tudo o que fora a existência dele apesar de tantos casos tanta brincadeira tanta ilusão tanto sofrimento tanto heroísmo, afinal não fora sinão um se deixar viver; e pra parar na cidade do Delmiro ou na ilha de Marajó que são desta terra carecia de ter um sentido. E ele não tinha coragem pra uma organização (ANDRADE, 2007, p. 208). 
Isso não significa que o malandro seja necessariamente inadaptado. Pode estar adaptado na sua marginalidade, desde que não seja tão entregue ao princípio do prazer, como é Macunaíma. Contudo, a vadiagem inerente ao malandro o impedirá de ascender socialmente, ao contrário do que ocorre com o típico trickster.

A outra diferença essencial é que o trickster, ao aprender técnicas, desenvolve tecnologias que aproveitam aos seres humanos, pois costumam tratarse de seres primordiais, com as consequências de suas ações estendendo-se a toda a humanidade através dos tempos. Com o malandro ocorre exatamente o oposto, suas ações têm caráter essencialmente individual e sem consequências para terceiros (salvo o otário eventualmente por ele ludibriado). Embora Macunaíma pratique algumas ações que definem contornos do mundo, o aproximando do trickster, como fazer a sol ficar amarela ao arremessar um ovo contra ela, ou criar as crateras lunares após socar o satélite, nenhuma de suas ações gera tecnologias aproveitáveis ao ser humano, como ocorre no caso da maioria dos tricksters, que são chamados de heróis-civilizadores (HYDE, 2008, Introduction, p. 18-19) ${ }^{3}$. Ao contrário, o fato de Macunaíma ter o poder de traçar feitios do mundo, mas não fazer absolutamente nada de proveitoso ao ser humano, reforça seu caráter individualista, marca do malandro.

Voltemos então à pergunta: o que implica, Mário de Andrade, ao ressignificar um trickster como malandro nacional?

O autor modernista parece propor que a separar o malandro que se dá mal (como é o caso de Macunaíma, mas evidentemente não de todos os malandros) do "malandro" que se dá bem, ou seja, o trickster, está a capacidade de contenção, ou seja, a renúncia. $O$ verdadeiro herói nacional ${ }^{4}$ praticará a renúncia. Não só a renúncia, mas uma renúncia socialmente engajada (caráter coletivo, em oposição ao individualismo do malandro e de Macunaíma). Como disse Roberto DaMatta:

Malandros e caxias prometem carnavais e paradas. $O$ renunciador promete um mundo novo, um universo social alternativo, como o fez Antônio Conselheiro e, em escala menor, todos os nossos cangaceiros ou bandidos sociais, como foi o caso de Lampião e outros. Ousaria, então, dizer que tudo indica ser o renunciador o verdadeiro revolucionário num universo social hierarquizante, como é

\footnotetext{
${ }^{3}$ Consultamos este livro no formato Epub, na plataforma Kobo Glo. A numeração reinicia a cada sessão, daí a necessidade de se incluir a referência a "introduction". Ademais, ressalte-se que a numeração de páginas pode variar entre plataformas e o tamanho de fonte usada.

${ }^{4}$ Como Mário de Andrade esclarece: "Me repugnaria bem que se enxergasse em Macunaíma a intenção minha dele ser o herói nacional. É o herói desta brincadeira, isso sim (...)" (ANDRADE, 2007, p. 227).
} 
o caso do sistema brasileiro. (...) O objetivo dos renunciadores é recriar uma nova sociedade e um novo tempo. (DAMATTA, 1983, p. 206, grifos do autor)

Ao destacar um trickster, tipo capaz de, após aprendizado, praticar a renúncia, e ressignificá-lo como malandro, Mário de Andrade aponta para esta ausência de renúncia. O escritor parece aguardar pelo renunciador que se apresentará como herói nacional. Não apenas nacional, mas ao menos sul-americano. Não devemos esquecer que o autor escolheu um herói transnacional e que ele faz questão de ressaltar essa transnacionalidade: "O próprio herói do livro que tirei do alemão de Koch-Grünberg, nem se pode falar que é do Brasil. É tão ou mais venezuelano quanto da gente [...]" (ANDRADE, 2007, p. 226).

Joaquim Pedro de Andrade, diretor do filme Macunaíma, captou e registrou com maestria a significação do "herói de nossa gente":

O que falta ao personagem Macunaíma é uma visão mais geral, mais ambiciosa e mais consciente. Ele dá sempre os seus golpes com objetivo limitado, pessoal, individualista. É um estágio vencido - mas importante - do que seria o caminho para o herói moderno brasileiro. Macunaíma é o herói derrotado, que acaba comido pela lara, abandonado e traído. (...)

O herói moderno, para mim, é uma espécie de encarnação nacional, cujo destino se confunde com o próprio destino de seu povo. Uma das características fundamentais é a falta de consciência coletiva. Ao contrário de Macunaíma, ele terá de encarnar um ser moral, no sentido de estar possuído por toda uma ética social. Ainda não apareceu o herói moderno simplesmente porque ele terá de ser um vencedor, ao contrário do herói romântico, que era o herói vencido, triste. Em suma, o herói moderno terá de ser evidentemente uma superação de Macunaíma, embora conservando algumas características dele (ANDRADE, 1978, p. 101).

\section{Conclusão}

Em conclusão, vale a pena olhar para o que diz Etienne Balibar acerca da necessidade que há nas nações de se "etnicizarem", ou seja, formar uma comunidade nacional como se sempre tivessem sido e sempre fossem uma coisa só:

Nenhuma nação possui uma base étnica natural. À medida que grupos sociais são nacionalizados, as populações neles incluídas, seus sub-grupos e os povos dominadas por eles são etnicizados, isto é, são representados no passado e no futuro como se formassem uma comunidade natural, possuidora de uma identidade de origens, 
cultura e interesses que transcendem os indivíduos e as condições sociais (BALIBAR, 2002, p. 96; tradução livre) ${ }^{5}$.

$E$, mais à frente, acrescenta: "É a etnicidade fictícia que possibilita que a expressão de uma unidade pré-existente seja vista no estado" (BALIBAR, 2002, p. 96; tradução livre $)^{6}$. Pensando em Macunaíma como mediador das principais raças fundadoras do país e levando em conta as palavras de Joaquim Pedro de Andrade, segundo as quais o herói nacional será uma superação de Macunaíma, mas conservará algumas características do personagem, talvez esse futuro herói macunaístico-renunciador imaginado pelo Andrade cineasta e (provavelmente) pelo Andrade escritor, seja o sujeito a conseguir, rompendo a estagnação das estruturas sociais, fazer a mediação entre os diferentes estratos e raças, promovendo uma costura que permitirá, por meio da aniquilação ou minimização das diferenças baseadas na imobilidade social, criar a unificação nacional a que Balibar se refere, viabilizando, a futuros brasileiros, uma movimentação entre estratos sociais que não guardarão, entre si, a diferença que há hoje e havia ainda mais às épocas de ambos os andrades. Sem dúvida sempre existirá resistência por parte da camada dominante, daí a necessidade de o caráter heroico/renunciador fazer-se presente, a fim de superá-la.

\section{Referências}

ANDRADE, Joaquim Pedro de. Sem título. In: HOLANDA, Heloísa Buarque de. Macunaíma: da literatura ao cinema. Rio de Janeiro: J. Olympio, 1978.

ANDRADE, Mário de. Macunaíma: o herói sem nenhum caráter. Belo Horizonte: Villa Rica Editoras Reunidas, 2007.

BALIBAR, Etienne. The Nation Form: History and Ideology. Race, nation, class. New York: Verso, 2002

BARRETO, Renato Amado. Os princípios do Prazer e da Realidade no Trickster Macunaíma. Revista Trama, v. 12, n. 27, p. 202-226, 2016. Disponível em: <http://erevista.unioeste.br/index.php/trama/article/view/14435>. Acesso em: 12 set. 2017.

\footnotetext{
${ }^{5}$ No original: "No nation possesses an ethnic base naturally, but as social formations are nationalized, the populations included within them, divided up among them or dominated by them are ethnicized that is, represented in the past or in the future as if they formed a natural community, possessing of itself an identity of origins, culture and interests which transcends individuals and social conditions".

${ }^{6}$ No original: "It is fictive ethnicity which makes it possible for the expression of a pre-existing unity to be seen in the state".
} 
BARRETO, Renato Amado; OLIVEIRA, Ana Lúcia Machado de. Makunaima e Macunaíma: dois Tricksters. Caderno de Letras, n. 26, p. 277-309, 2016. Disponível em: https://periodicos.ufpel.edu.br/ojs2/index.php/cadernodeletras/article/view/8518>. Acesso em: 24 dez. 2017.

BENJAMIN, Walter. Origem do Drama Barroco Alemão. São Paulo: Brasiliense, 1984.

CAMPOS, Haroldo de. Morfologia do Macunaíma. São Paulo: Perspectiva, s/d.

CÂNDIDO, Antônio. Dialética da Malandragem. Revista do Instituto de estudos brasileiros, n. 8, p. 67-89, 1970. Disponível em: <http://www.revistas.usp.br/rieb/ article/view/69638>. Acesso em: 23 fev. 2016.

CARVALHO, Fábio Almeida de; JOBIM, José Luis. "Makunaima/Macunaíma: os caminhos de um personagem transnacional". In: JOBIM, José Luis. Literatura e cultura: do nacional ao transnacional. Rio de Janeiro: EDUERJ, 2013.

DAMATTA, Roberto. Carnavais, Malandros e Heróis. Rio de Janeiro: Zahar, 1983.

FREUD, Sigmund. Formulações sobre os dois princípios do funcionamento psíquico. In: Obras completas volume 10: observações psicanalíticas sobre um caso de paranoia relatado em autobiografia ("o caso Schreber"), artigos sobre técnica e outros textos (1911-1913). São Paulo: Companhia das letras, 2010.

. Além do princípio do prazer. Disponível em: <http://lacan.orgfree.com/freud/ textosf/alemdoprincipiodeprazer.pdf>. Acesso em: 11 ago. 2015.

HANCIAU, Nubia Jacques. O entre-lugar. In: FIGUEIREDO, Eurídice (Org.). Conceitos de literatura e cultura. Juiz de Fora, MG/Niterói, RJ: Editora UFJF/EdUFF, 2010.

HYDE, Lewis. Trickster Makes This World: Mischief, Myth, and Art. Nova York: Farrar, Straus and Giroux, 1998.

JUNKES, Lauro. O Processo de Alegorização em Walter Benjamin. Anuário de Literatura 2, p. 125-137, 1994. Disponível em: <https://periodicos.ufsc.br/index.php/ literatura/article/view/5361>. Acesso em: 05 dez. 2016.

KOCH-GRÜNBERG, T. Mitos e lendas dos índios Taulipáng e Arekuna. In: MEDEIROS, Sérgio. Makunaíma e Jurupari: cosmogonias ameríndias. São Paulo: Perspectiva, 2002.

LÉVI-STRAUSS, Claude. Antropologia Estrutural. São Paulo: Cosac Naify, 2012.

MATOS, Cláudia Neiva de. Acertei no Milhar: malandragem e samba no tempo de Getúlio. São Paulo: Paz e Terra, 1982. 
$\mathbb{B}_{\text {dissei }} \mathcal{A}$

PEREIRA, Catarina; GUEDES, Maria Sebastiana. Macunaíma Multicultural e Alegórico: Facetas do Discurso de Mário de Andrade. XIV ABRALIC, 2015, Belém. Anais Eletrônicos, p. 1-10. Disponível em: <http://www.abralic.org.br/anais/arquivos/ 2014_1434477443.pdf>. Acesso em: 05 dez. 2016.

PRANDI, Reginaldo. Mitologia dos Orixás. São Paulo: Companhia das Letras, 2001.

PROENÇA, Manoel Cavalcanti. Roteiro de Macunaíma. 5.ed. Rio de Janeiro: Civilização Brasileira, 1978.

RADIN, Paul. The Trickster. A Study in American Indian Mythology. New York: Philosophical Library, 1956.

ROUANET, Sérgio Paulo. Apresentação. In: BENJAMIN, Walter. Origem do Drama Barroco Alemão. São Paulo: Brasiliense, 1984.

SAFOUAN, Moustapha. O fracasso do princípio do prazer. Campinas, SP: Papirus, 1988.

SOUZA, Gilda de Mello e. O tupi e o alaúde. 2. ed. São Paulo: Editora 34, 2003.

Recebido em 24/12/2017

Aceito em 26/04/2018

Publicado em 21/05/2018 